\title{
Памяти события: об истории Спасо-Преображенского Воротынского монастыря и проекте достопримечательного места
}

\author{
Э.А.Шевченко, НИИТИАГ, Москва
}

Статья посвящена событию, отстоящему от нас более чем на 500 лет, - Великому стоянию на Угре.

Несмотря на то, что юбилей события прошел, о нём следует говорить ещй и ещё. Сегодня очень немногие соотечественники знают о том, что это было за «Стояние» и почему так важно нам всем праздновать это знаковое, для Отечества и всех его граждан событие название которому «Великое стояние на Угре». Именно здесь на реке Угре в 1480 году произошло событие не менее значимое, чем наши Победы в смутные времена и в 1812 и 1945 годах.

Поэтому так важно донести как можно большему числу соотечественников об этом Великом для страны событии и добиться, чтобы территория на которой оно происходило, было зафиксировано как объект культурного наследия в виде достопримечательного места. Сейчас монастырь, воздвигнутый Воротынским в честь великого события, лишился значительных территорий и, самое печальное, утрачивается историческая природная среда, сохранившая еще свою первозданность и аутентичность.

Ключевые слова: достопримечательное место, Спасский Воротынский монастырь, знаковое для Отечества и государства событие на Угре 1480 года, дух Места.

In Memory of the Event: on the History of the SpasoPreobrazhensky Vorotynsky Monastery and the Project of the Landmark

\section{E.A.Shevchenko, NIITIAG, Moscow}

The article is devoted to the Great Stand on the Ugra River from which more than 500 years have passed. Today, very few compatriots know what kind of "Stand" it was and why it is so important to celebrate it. It took place on the Ugra River in 1480 and was noless significant than Victories in the Time of Troubles and in 1812 and 1945. Therefore, it is important to convey to as many compatriots as possible about this great event for the country and to achieve the fixation of the territory on which it took place as an object of cultural heritage in the form of a landmark.

Now the monastery, erected by Vorotynsky in honor of the great event, has lost significant territories and, the saddest thing, the historical natural environment, which still retained its primordiality and authenticity, is beinglost.
Keywords: landmark, the Spassky Vorotynsky monastery, the Great Stand on the Ugra River in 1480, the spirit of the place.

В 2010 году по просьбе настоятельницы Казанского девичьего монастыря игуменьи Анастасии сотрудниками института НИИТИАГ был выполнен проект обоснования границ территории объекта культурного наследия, расположенного в районе возрождаемого Спасо-Преображенского Воротынского монастыря на реке Угре. В данном случае речь шла о сохранении историко-культурного и природного наследия и создании условий для эффективного развития социокультурного комплекса, включающего Спасо-Преображенский Воротынский монастырь, что недалеко от Калуги, и село Спас, расположенное в непосредственной близости от монастыря.

Территория, на которой располагается монастырь называется Угорщиной, и именно здесь в 1480 году произошло так называемое Великое стояние на Угре, ознаменовавшее практическое падение золотоордынского ига на Руси, длившегося более двух веков - с 1237 по 1480 годы.

Цель проекта была очевидна изначально - сохранение «духа Места» в районе Великого стояния и мемориального Спасо-Преображенского Воротынского монастыря, воссоздание монастырского комплекса на период его расцвета (XVI - начало XVII века), использование и популяризация Места стояния как ценнейшего достояния народов Российской Федерации, обладающего сакральной, исторической, культурной и природной ценностью, поднятие духовной культуры социума, восстановление исторической справедливости, увековечивание памяти Великого стояния на Угре и роли Спасо-Пребраженского Воротынского монастыря в судьбе становления Российского государства на рубеже XV-XVII веков.

Гражданское значение монастыря трудно переоценить. Он располагается на землях, где на протяжении нескольких столетий шла упорная борьба за приобретение Русью государственной независимости, недопущение проникновения католицизма на Русь путём церковного слияния с Западом, сохранение Руси как православного государства, возвращение исконно русских земель, захваченных в 1405 году литовским князем Витовтом. Исходя из этого была определена цель проекта, поставлены следующие 
задачи - определение вида объекта культурного наследия, в большей степени отвечающего необходимости сохранения целостного уникального историко-культурного и природного наследия, охватывающего большую по площади территорию, обоснование границ и установление статуса объекта культурного наследия. С самого начала разработки проекта было понятно, что поиски должны быть направлены на доказательство установления вида объекта культурного наследия в виде достопримечательного места - «Мемориал “Спас на Угре"».

Главным, основополагающим критерием ценности исследуемого объекта, требующего сохранения и охраны является уникальное наследие - дух Места, на землях которого решилась судьба будущего государства российского, то есть произошло стояние дружин Ивана III и хана Ахмата на Угре, зафиксировавшее победу Руси в борьбе за независимость от золотоордынского ига. Фактически события 1480 года можно приравнять по своей исторической и социальной значимости к Бородинскому сражению, сражению под Малоярославцем 1812 года и Великой Победе 1945 года.

При разработке проекта были использованы архивные материалы Российского государственного архива древних актов: Ф. 210. Ст. Приказного стола № 2017; Ф. 1209, ед. хр. 84, лл. 365, 366, 368; Ф. 280, 1763 г., ед. хр. 524; Ф. 1354, оп. 750, ед. хр. 39-С.

Отдельно надо отметить данные ЦГАДА, свидетельствующие о дате упразднения монастыря, которые расходятся с датами, приводимыми исследователями калужской старины. Так, П. Шелетов-Самгин в «Памятной книжке Калужской губернии» (Калуга, 1861, стр. 272) считает, что монастырь был закрыт в 1860 году. Леонид Кавелин (Церковно-историческое описание упраздненных монастырей в Калужской епархии. M, 1863. - С. 95) полагает, что упразднение монастыря произошло в 1725 году согласно Духовного регламенту, по которому происходило объединение мелких обителей.

Обе эти даты ошибочны. В ЦГАДА сохранился ряд монастырских документов середины XVIII века, которые свидетельствуют о существовании монастыря до 1764 года (ЦГАДА. Ф. 281. Грамоты Коллегии Экономии по Калужскому уезду. Ед. хр. 2309, 2310; ЦГАДА. Ф. 280 «Офицерские описи», 1763 г., ед. хр. 524).

В 2010 году это была одна из первых работ по сбору доказательной базы для установления вида объекта культурного наследия «Достопримечательное место» и обоснованию границ территории объекта, как того требует закон «0б объектах культурного наследия...»¹. 0пыта разработки подобных проектов тогда не было, и мы приняли методику установления границ зон охраны, в основе которой лежал визуальный анализ территории.

\footnotetext{
1 Федеральный закон «0б объектах культурного наследия (памятниках истории и культуры) народов Российской Федерации» от 25.06.2002 N 73-Ф3 (последняя редакция) (http://www.consultant.ru/document/ cons_doc_LAW_37318/).
}

Особую роль в установлении границ территории, обладающей историко-культурным потенциалом, в данном случае играют водные пространства рек 0ки и Угры как неотъемлемая и основополагающая часть пространственной структуры будущего мемориала. Эта территория вместе с природно-антропогенным ландшафтом представляет целостный и богатейший по историко-культурному потенциалу комплекс. Это крупная пространственная «единица» территории, не зависящая от состояния, настроения и мировоззрения индивида, воспринимающего эту представляющую природный комплекс пространственную «единицу», является самой устойчивой по степени сохранности пространственной «единицей» формируемого объекта культурного наследия. В данном случае мы говорим об ином предмете охраны - объекте, требующем сохранения, но не обладающего редкими или уникальными природными данными. То есть мы подразумеваем наличие сложного антропогенно-природного комплекса, состоящего из объектов материальной культуры: монастыря, городища, исторического села, - территории, хранящей информационный потенциал в виде памяти о событиях и явлениях духовной и материальной жизни.

Историко-культурный потенциал Места довольно специфичен и проявляется в сохранившихся планировочной структуре, типичной для сельских поселений, природном ландшафте, типичном для среднерусской возвышенности, живописно расположенной одно-, двухэтажной застройке, являющейся характерным примером сохранившейся патриархальной сельской планировочной структуры в природной среде.

Долгое время татарские нашествия были ограничены руслами рек Оки и Угры. Наверное, по этой причине в Казанской летописи об Угре говорится: «и могу нареши ту реку пояс самые Пречистые Богородицы, аки твердь от поганых защищающу Русскую землю». Поэтому за Угрой закрепилось название «пояса Богоматери».

B XIV-XV веках берега Угры служили естественной границей между Московским княжеством и Литвою. На пограничной территории, включающей части правого берега реки Угры и левого берега реки Оки, располагался удел подданных польско-литовского короля князей Воротынских с княжеской резиденцией в городе Воротынске на реке Высе (современное село Воротынское).

В конце XV века Москва начала заявлять свои притязания на исконно русские земли, захваченные Литвой в середине XIV века и, в первую очередь, на левобережье Оки.

В 1480 году золотордынский хан Ахмат, задумав в середине лета поход на Москву через Литву, его союзницу, пытался перейти реку Угру у устья. Именно здесь, у устья, хан Ахмат расположил лагерь. Поход в глубь Руси не получился, так как войска хана были остановлены московским войском Ивана III (позднее на этом месте возник Спасский Воротынский монастырь). 
На сторону набиравшей силу Москвы стали переходить многие литовские подданные. Среди них были и русские православные князья Воротынские, род которых ведёт свое начало от черниговского князя Михаила Всеволодовича.

В 1484 году на сторону Руси перешёл князь Михаил Федорович Воротынский, в 1493-ем за ним последовали братья Дмитрий и Симеон Федоровичи и их племянник Иван Михайлович Перемышльский.

По демаркации 1494 года Литва была вынуждена признать земли Воротынских за русским государством.

Вероятнее всего именно в это время князья Воротынские, занимаясь возрождением своей родовой вотчины, могли основать в ней мужской монастырь, ставший на вновь обретённой русской территории символом утверждения Московского государства и торжества православной веры.

«Великое стояние на Угре» 1480 года продолжалось до начала ноября, после чего хан был вынужден отступить и, как говорит летописец, «бежа в Орду». Удачный исход начавшейся было войны завершил окончательное освобождение русского государства от татаро-монгольского ига. События 1480 года, явившиеся переломным рубежом в русской истории, могли оказать решающее влияние на выбор местоположения основанного Спасского монастыря.

В «Материале для историко-топографического исследования о православных монастырях в Российской Империи» (составитель В.В. Зверинский) о Спасском Воротынском монастыре сказано следующее: «Спасский - Воротынский, что на Усть-Угры, мужской, ныне село Спасское, Калужской губ., Перемышльского уезда, в 28 верстах к северу от Перемышля, при впадении р. Угры в Оку. Полагают, что основан около 1480 г. в память заступления Божией Матери от нашествия татар, но несомненно существовал в 16 столетии, так как в притворе Введенской церкви сохранилась плита с надписью: “7115 (1607 г.) преставился инок Евфимий”. В 1665 г. приписан к Крутицкому архиерейскому дому, в 1725 г. запустел».

Обращение к данному изданию неслучайно, так как одной из задач подготовки данного проекта было выяснение времени основания монастыря или первого исторического упоминания о нём, уточнения географического положения, что совпадало с основной задачей В.В. Зверинского - составителя «Материала для историко-топографического исследования о православных монастырях в Российской Империи»: «... задачею было указать: что осталось от монастыря в настоящее время...», то есть к 1880 году. Однако В.В. Зверинский только подтвердил факт лишения монастыря самостоятельности, вследствие чего, через 60 лет монастырь запустел и был упразднён. Относительно времени его создания он (В.В. Зверинский) как и многие исследователи предполагает, что монастырь был основан около 1480 года.

Думается, что вероятным временем его создания может быть либо год 1484-й - год перехода на сторону Руси князя Михаила Фёдоровича Воротынского, либо, 1493-ий - когда на сторону Руси перешли его братья Дмитрий и Симеон
Фёдоровичи, а также их племянник Иван Михайлович Перемышльский. Более того, исторические источники связывают создание монастыря с именем Дмитрия Фёдоровича, и если это так, то ранее времени своего перехода на сторону Руси он не мог осуществить этого плана, следовательно, можно говорить о 1493 годе, но не ранее.

В подтверждение факта основания монастыря князем Дмитрием Фёдоровичем Воротынским приводятся данные из исторической литературы XIX века, где есть сведения о том, что еще в конце XIX века в церкви Преображении в селе Спас хранился монастырский синодик 1693 года, переписанный с более древнего оригинала. Среди частных родов род князей Воротынских помещён в нем первым, а среди Воротынских в поминальном списке первым значится Дмитрий Фёдорович. Тем самым он выделен особо, так как имя его старшего брата стоит вторым, а имя отца даже третьим, что и подтверждает его особые заслуги в деле укрепления православия на Руси.

Но наиболее вероятным временем может быть 1494 год, когда по демаркации Литва была вынуждена признать земли Воротынских за русским государством (для уточнения времени возникновения на этой территории монастыря необходимо повести археологические исследования).

В процессе выполнения проектных работ был проанализирован «Проект охранной зоны и зоны регулирования застройки памятника архитектуры XVI-XVIII вв. Спасского Воротынского монастыря Калужской области» 1976 года. Благодаря тщательности обоснования, выполненного в 1976 году, были выявлены неизвестные ранее архивные источники, в которых содержится информация, что Спасский монастырь «на усть-Угре реки» в 1511 году по жалованной грамоте великого князя Василия Ивановича владел перевозом через Угру у Большой Брянской и Калужской дорог. Из упомянутого источника следует, что в 1511 году монастырь уже существовал.

Однако следует отметить, что к середине XVIII века монастырь, как самостоятельная обитель, не существовал уже более пятидесяти лет, но тем не менее присутствовал на данной территории в качестве напоминания о событиях многовековой давности и значимости этих мест в истории формирования государства.

Нас интересовал не только период расцвета монастыря до его приписки к Архиерейскому дому, но очень важно было, по возможности, установить какую эмоциональную и идеологическую роль, кроме просветительской и духовной, играл Спасский - Воротынский монастырь как до 1665 года, так и весь последующий период времени.

От момента приписки монастыря к Крутицкому Архиерейскому дому до момента принятия в 1764 году Екатериной II Указа о «Духовных штатах», прошло сто лет. Этим Указом в одночасье было упразднено в России 56,3\% монастырей. «Такое значительное сокращение числа обителей, - как пишет B.В, Зверинский, - между которыми находилось много существовавших исстари, не могло не произвести удручающего впечатления как на монашествующих, так и на окрестное население». 
Следует отметить, что для судьбы Спасского Воротынского монастыря Указ Императрицы большого значения уже не мог иметь, так как к этому времени он уже был лишён своей самостоятельности и пришёл в упадок.

Как сообщает тот же В.В. Зверинский, «приписка обителей к архиерейским домам ... равносильна упразднению, потому что всё, что есть ценного... переносится в главный монастырь, куда переводятся на жительство и иноки... нередко приписной монастырь остаётся под присмотром одного сторожа...». Монастырь, по сути, был обречён на упразднение. Более того, монастыри архиерейского дома существовали в другой форме. Они не могли оказывать того влияния на окрестное население, которое имели обычные монастыри, так как живущие в них в большей степени, как сообщает В.В. Зверинский, были «немонашествующие, да и самый доступ в эти святыни ограничен для простого народа...».

С уничтожением Спасо-Воротынского монастыря уничтожалась мемориальная и сакральная память о событиях великих побед прошлых веков, уничтожалась значимость событий 1480 года. Вероятно, отголоском такого безразличия к памяти о минувших событиях и их значимости стало высказывание автора интереснейшей концепции пассионарности Л.Н. Гумилёва, о событиях противостояния на Угре: «Легко понять, что стояние на Угре было лишь эпизодом в длительной борьбе двух коалиций: новгородско-литовско-золотоордынской и московско-касимовско-крымской. И уж... нет никаких оснований считать, будто стояние на Угре ознаменовало собой “свержение ордынского ига”. ...Да и современники воспринимали войну с Ахматом не как свержение ига, а как войну за веру с нечестивым противником, врагом православия».

По всей вероятности, в период, когда Л.Н. Гумилёв занимался исследованием упомянутого вопроса, главным было доказать, что ига не было, а был политический сговор. Пусть так, но разве это повод умалять значимость события, ставшего ключевым в истории взаимоотношений двух противоборствующих политических сил и самым положительным образом повлиявшего на судьбу молодого «государства» - Великого княжества Московского.

06 истинной значимости стояния на Угре говорят многие летописные источники, в частности Лицевой летописный свод XVI века «0 царе Ахмате как приходил на Угру». Исследования, проведённые Е. Чайкиным, посвящённые Великому стоянию на Угре и опубликованные в его книге «Угорщина. Великое стояние на реке Угре»², имели целью восполнить пробел в публикациях о далёких, но таких значимых событиях истории нашего государства.

Возникновение монастыря именно на месте, где предположительно располагалась стоянка Ахмата (отсутствие археологических исследований на данной территории не позволяет с уверенностью это утверждать), было выбрано

2 Чайкин Е.В. Угорщина. Великое стояние на реке Угре. - Калуга : Облиздат., 2000. - 119 с.
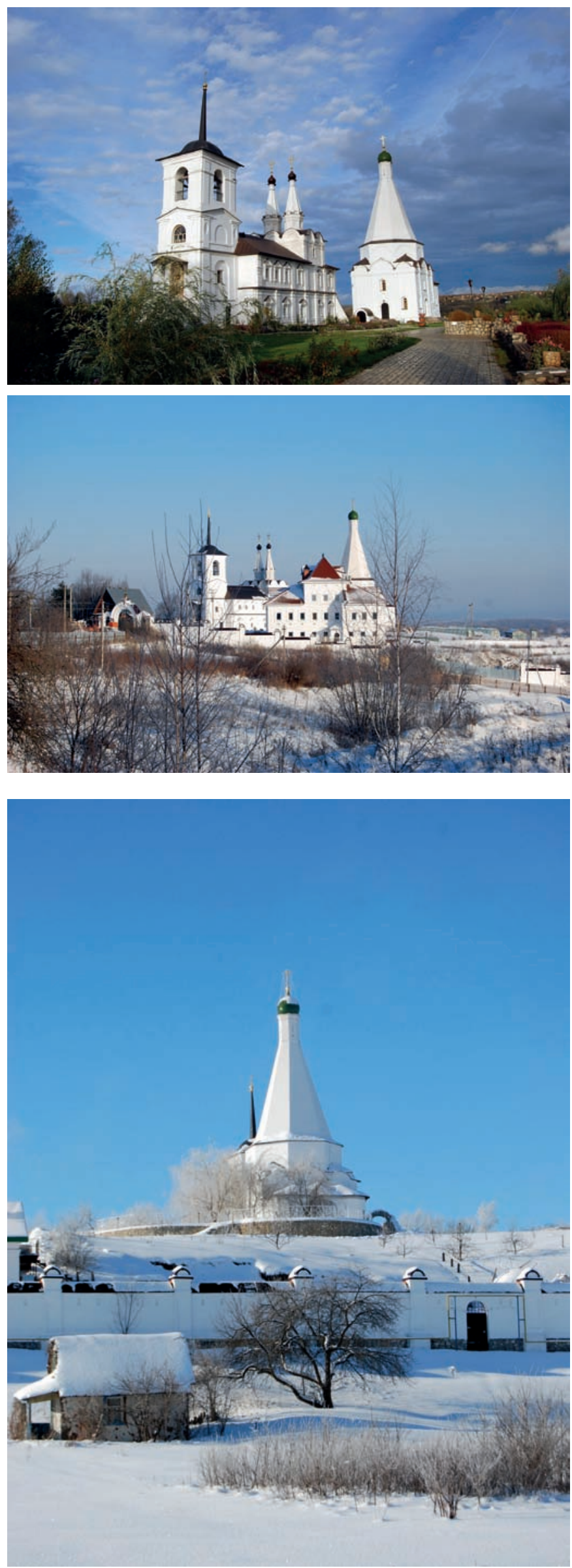

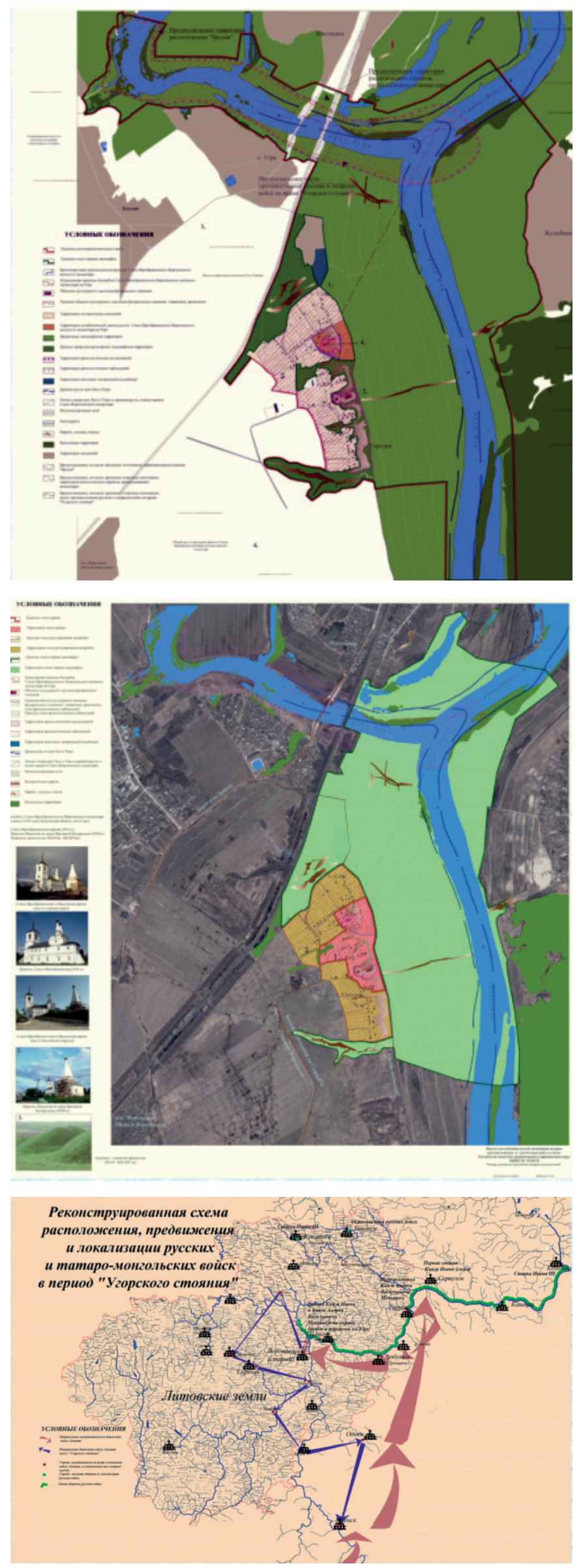

князем Воротынским исключительно верно: построив на этом месте православную обитель, он возвысил православную веру. Он увековечил славу русского оружия и доблести, он отстоял земли, некогда принадлежавшие мелким русским князьям и завоёванные литовцами, вернув их в лоно нового, нарождающегося Российского государства.

В этой связи естественно доминантное положение монастыря над пойменными землями рек Угры и Оки. Главенствуя над территорией, монастырь является притягательной силой для населения близлежащих сёл и деревень. Он опора веры и государства.

Наиболее интенсивное строительство шатровых храмов монастыря приходится на 1553-1570 годы, то есть на период наивысшего расцвета военной мощи Русского государства. Эти же годы (за вычетом четырёх лет) - время расцвета военной деятельности князя Михаила Ивановича Воротынского и его брата Александра. Логично допустить, что в Спасском монастыре, расположенном в родовой вотчине Воротынских, шатровый храм во имя Преображения возник как сооружение мемориальное.

На основании стилистических признаков главный храм монастыря датируется второй половиной XVI века. Русское шатровое зодчество этого времени тесно связано с идеологией московского централизованного государства. Столпообразные храмы-памятники нередко имели мемориальное назначение и ставились в память знаменательных событий, чаще всего - военных побед.

В связи с упоминанием в Большом Чертеже, важно подчеркнуть, что просматриваемые с большого расстояния шатровые монастырские постройки могли выполнять роль ориентиров-маяков на судоходной Оке.

Монастырь Спасский «на усть Угре на Оке» отмечен в «книге глаголемая Большой Чертёж» 1627 года, которая является пояснением к утраченной карте Московского государства, составленной на русском языке в XVI веке. Пометка на древней карте Московского государства весьма убедительно свидетельствует о существенном значении древней обители, основанной у слияния двух рек, входивших в систему водных путей «из варяг в греки» и соединённых с Волгой.

Как сказано в пояснительной записке проекта, «в орбиту проектных предложений был включён и социум как наиважнейший компонент социокультурного комплекса данной территории. Проект направлен на восстановление (воссоздание), сохранение, изучение территориального комплекса культурного и природного наследия на месте Великого стояния на Угре, установление правовых норм охраны подобных объектов культурного наследия».

Хочется подчеркнуть, что цель проекта заключалась не только в сохранении «духа Места» в районе Великого стояния на Угре и мемориального Спасо-Преображенского Воротынского монастыря, воссоздании монастырского комплекса на период его расцвета (XVI - начало XVII века), использовании и популяризации исторической среды этого 
Места как ценнейшего достояния народов Российской Федерации, обладающего сакральной, исторической, культурной и природной ценностью, но и в поднятии духовной культуры социума, восстановлении исторической справедливости, увековечивании памяти Великого события в истории Отечества - Великом стоянии на Угре, и роли Спасского Воротынского монастыря в судьбе становления Российского государства на рубеже XV - XVII веков ${ }^{3}$.

\section{Лumepamypa}

1. Pannanopm, П.А. Русское шатровое зодчество конца XVI века / П.А. Раппапорт // В кн.: Материалы и исследования по археологии Москвы. Том II / Материалы и исследования по археологии СССР; № 12. - М.-Л., 1949. - С. 238-301.

2. Беляев, Л.А. Спасский «на Усть-Угре» монастырь в XVI веке (археология, история архитектура) / Л.А. Беляев // Реставрация и архитектурная археология. Новые материалы и исследования : Сборник статей. Вып. 2. - М. : Мейкер, 1995. - С. 55-72.

3. Прозоровский, А. Воротынский Спасский монастырь / А. Прозоровский // Калужские епархиальные ведомости. - 1891. - № 8.

4. Экземплярский, А.В. Великие и удельные князья Северной Руси в татарский период с 1238 по 1505 гг. Т. 2 / А.В. Экземплярский. - СПб, 1891.

5. Пресняков, А.Е. Лекции по русской истории. Т. 2. Западная Русь и Литовско-Русское государство / А.Е. Пресняков. - М., 1939.

6. Рыбаков, Б.А. Русские карты Московии XV - нач.XVI в. - М., 1974. - 111 c.

7. Мосин, О.В. Древнейшие поселения Калужской области [Электронный ресурс] / О.В. Мосин // Журнал «Самиздат». - 2009. - Режим доступа: http://samlib.ru/o/oleg_w_m/cdo cumentsandsettingsolegmoidokumentydrevnostrtf.shtml (дата обращения 10.11.2020).

8. Кавелин, Л. Церковно-историческое описание упразднённых монастырей в Калужской епархии / Л. Кавелин. - М., 1863.

9. Кавелин, Л. Церковно-историческое исследование о древних областях вятичей, входящих в состав Крутицкой и частично Суздальской епархии / Л. Кавелин. - М., 1862.

10. Веселовский, С.Б. Последние уделы в Северо-Восточной Руси / С.Б. Веселовский // Исторические записки / Институт истории АН СССР. - 1947. - Вып. 22.

11. Спасский, Г. Книга, глаголемая Большой Чертёж / Г. Спасский. - М., 1846.

12. Зверинский, В.В. Материалы для историко-топографического исследования о православных монастырях в Российской Империи, с библиографическими указателями. Преобразование старых и учреждение новых монастырей с

${ }^{3}$ Однако разработанный проект обоснования территории этого уникального и знакового в истории государства события не был поддержан органами охраны наследия Калужской области.
1764-95 по 1 июля 1890 год / В.В. Зверинский. - СПб : Типогр. В. Безобразова и Комп., 1890.

13. Археологические исследования в РСФСР 1934-1936 гг. - М.-Л., 1941.

\section{References}

1. Rappaport P.A. Russkoe shatrovoe zodchestvo kontsa XVI veka [Russian tent architecture of the late 16th century / P.A. Rappaport]. In: Materialy $i$ issledovaniya po arkheologii Moskvy. Tom II: Materialy $i$ issledovaniya po arkheologii SSSR [Materials and research on the archeology of Moscow. Volume II / Materials and research on archeology of the USSR], no. 12. Moscow-Leningrad, 1949, pp. 238-301.

2. Belyaev L.A. Spasskii «na Ust'-Ugre» monastyr' v XVI veke (arkheologiya, istoriya arkhitektura) [Spassky "on UstUgra" monastery in the 16th century (archeology, history of architecture)]. In: Restavratsiya i arkhitekturnaya arkheologiya. Novye materialy $i$ issledovaniya [Restoration and architectural archeology. New materials and research: Collection of articles], Is. 2. Moscow, Meiker Publ., 1995, pp. 55-72.

3. Prozorovskii A. Vorotynskii Spasskii monastyr' [Vorotynsky Spassky Monastery]. In: Kaluzhskie eparkhial'nye vedomosti [Kaluga Diocesan Gazette], 1891, no. 8.

4. Ekzemplyarskii A.V. Velikie i udel'nye knyaz'ya Severnoi Rusi v tatarskii period s 1238 po 1505 gg. [Great and appanage princes of Northern Russia in the Tatar period from 1238 to 1505], Vol. 2. Saint Petersburg, 1891.

5. Presnyakov A.E. Lektsii po russkoi istorii. T. 2. Zapadnaya Rus' i Litovsko-Russkoe gosudarstvo [Lectures on Russian history. Vol. 2. Western Russia and the Lithuanian-Russian state]. Moscow, 1939.

6. Rybakov B.A. Russkie karty Moskovii XV - nach. XVI v. [Russian maps of Muscovy of the 15th - early 16th centuries]. Moscow, 1974, $111 \mathrm{p}$.

7. Mosin 0.V. Drevneishie poseleniya Kaluzhskoi oblasti [The most ancient settlements of the Kaluga region]. In: Samizdat (magazine), 2009. Access mode: http://samlib.ru/o/ oleg_w_m/cdocumentsandsettingsolegmoidokumentydrevnos trtf.shtml (accessed 10.11.2020).

8. Kavelin L. Tserkovno-istoricheskoe opisanie uprazdnennykh monastyrei v Kaluzhskoi eparkhii [Churchhistorical description of the abolished monasteries in the Kaluga diocese]. Moscow, 1863.

9. Kavelin L. Tserkovno-istoricheskoe issledovanie o drevnikh oblastyakh vyatichei, vkhodyashchikh $v$ sostav Krutitskoi i chastichno Suzdal'skoi eparkhii [Church-historical research about the ancient regions of the Vyatichi, which are part of the Krutitsa and partially Suzdal diocese]. Moscow, 1862.

10. Veselovskii S.B. Poslednie udely v Severo-Vostochnoi Rusi [Last destinies in North-Eastern Russia]. In: Istoricheskie zapiski [Historical Notes], 1947, Is. 22.

11. Spasskii G. Kniga, glagolemnaya Bol'shoi Chertezh [The book, verbal Big Drawing]. Moscow, 1846. 
12. Zverinskii V.V. Materialy dlya istoriko-topograficheskogo issledovaniya o pravoslavnykh monastyryakh $\vee$ Rossiiskoi Imperii, s bibliograficheskimi ukazatelyami. Preobrazovanie starykh i uchrezhdenie novykh monastyrei s 1764-95 po 1 iyulya 1890 god [Materials for historical and topographic research on Orthodox monasteries in the Russian Empire, with bibliographic indexes. Conversion of old and establishment of new monasteries from 1764-95 to July 1, 1890]. Saint Petersburg, Tipogr. V. Bezobrazova i Komp. Publ., 1890.

13. Arkheologicheskie issledovaniya v RSFSR $1934-1936 \mathrm{gg}$. [Archaeological research in the RSFSR 1934-1936]. - MoscowLeningrad, 1941.

Шевченко Элеонора Арсеновна (Москва). Кандидат архитектуры, советник РААСН, действительный государственный советник Российской Федерации 3 класса. Ведущий научный сотрудник Научно-исследовательского института теории и истории архитектуры и градостроительства (филиал ФГБУ «ЦНИИП Минстроя России») (111024, Москва, ул. Душинская, 9. НИИТИАГ). Эл. почта: shegal1948@mail.ru.

Shevchenko Eleonora A. (Moscow). Candidate of Architecture, Adviser of RAACS, 3rd Class Full State Councilor of the Russian Federation. Leading Researcher at the Research Institute of Theory and History of Architecture and Urban Planning (9 Dushinskaya st., Moscow, 111024. NIITIAG), branch of the Central Institute for Research and Design of the Ministry of Construction and Housing and Communal Services of the Russian Federation (TsNIIP).E-mail: shegal1948@mail.ru. 